\title{
Originals
}

\section{Angiotensin II and the endocrine pancreas: effects on islet blood flow and insulin secretion in rats}

\author{
P.-O. Carlsson ${ }^{1}$, C. Berne ${ }^{2}$, L. Jansson ${ }^{1}$ \\ ${ }^{1}$ Department of Medical Cell Biology, Uppsala University, Uppsala, Sweden \\ ${ }^{2}$ Department of Internal Medicine, Uppsala University, Uppsala, Sweden
}

\begin{abstract}
Summary An intrinsic angiotensin system has been described in the pancreas, with angiotensin II specific receptors being present on both exocrine, endocrine and vascular cells. The aim of the present study was to evaluate the effects of angiotensin II on insulin secretion and blood flow regulation in the pancreas. Blood flows were determined with a microsphere technique. Infusion of angiotensin II induced a dosedependent reduction in both whole pancreatic and islet blood flow, which was most pronounced in the former. Administration of enalaprilate, an inhibitor of angiotensin-converting enzyme, and saralasin, a nonselective angiotensin II receptor antagonist, preferentially increased islet blood flow. The effects of angiotensin II on insulin release were examined by measuring insulin concentrations in the effluents from isolated perfused pancreata. In these preparations, enalaprilate affected neither basal nor glucose-stimu-
\end{abstract}

lated insulin release, whereas angiotensin II delayed the first phase of insulin release in response to glucose. The effect of angiotensin II was probably due to initial marked vasoconstriction. The retardation of insulin release could be avoided by adding angiotensin II to the perfusion medium 20 min before glucose administration, i.e. so that the vasoconstriction had disappeared when glucose-stimulation began. The present study suggests that the angiotensin-system is important in regulation of islet blood flow and points to a pivotal role of islet blood perfusion for an adequate insulin release. [Diabetologia (1998) 41: 127-133]

Keywords Renin-angiotensin system, ACE inhibitor, angiotensin II, pancreatic islets, insulin release, islet microcirculation
The activity of the renin-angiotensin system is of major importance for the maintenance of normal arterial blood pressure $[1,2]$. In recent years, mRNA encoding angiotensinogen has been demonstrated not only in the kidney and liver, but also in several other tissues [3-6]. Furthermore, high-affinity binding sites for angiotensin II (ATII) have been found in microvessels within these tissues [cf. 5, 7]. These

Received: 7 April 1997 and in revised form: 27 August 1997

Corresponding author: Dr. P.-O. Carlsson, Department of Medical Cell Biology, Biomedical Center, PO Box 571, S-751 23 Uppsala, Sweden

Abbreviations: ACE, Angiotensin converting enzyme; AT I, antiotensin I; ATII, angiotensin II; NIDDM, non-insulin-dependent diabetes mellitus. combined findings suggest that locally produced ATII may be involved in the regulation of the blood perfusion in several regional vascular beds. An intrinsic angiotensin-system has been demonstrated in the canine pancreas, where ATII-specific receptors occur on both endocrine, exocrine and vascular cells [5].

Despite the putative presence of its receptors, ATII has been reported to lack marked effects on the release of insulin or glucagon from isolated rat islets [8]. However, the islets used in these in vitro studies lack both blood supply and innervation, which is likely to affect their response to ATII. In view of the importance of ATII for local blood flow regulation and the presence of ATII-receptors in the pancreas of at least some species [5,9], the aim of the present study was to evaluate the effects of ATII on the blood 
perfusion in the exocrine and endocrine parts of the pancreas in vivo. We also intended to correlate possible ATII-induced changes in pancreatic blood flow to effects on insulin secretion by measuring insulin concentrations in the effluents of isolated perfused pancreata.

\section{Materials and methods}

Animals. Adult male Sprague-Dawley rats from a local breeding colony (Biomedical Center, Uppsala, Sweden) weighing approximately $350 \mathrm{~g}$ were used in all experiments. The animals had free access to pelleted food (Type R34; AB AnalyCen, Lidköping, Sweden) and tap water. All experiments were approved by the local animal ethics committee at Uppsala University.

Blood flow measurements. The animals were anaesthetized with an intraperitoneal injection of pentobarbital $(50 \mathrm{mg} / \mathrm{kg}$ body weight; Apoteksbolaget, Stockholm, Sweden), heparinized and placed on an operating table maintained at body temperature. Polyethylene catheters were inserted into the ascending aorta, via the right carotid artery, and into the left femoral artery. The former catheter was connected to a pressure transducer (PDCR 75/1; Druck Ltd., Groby, UK) and the mean arterial blood pressure was monitored throughout the experiments. The animals were allowed to stabilize their blood pressure until it remained constant ( $<5 \%$ variation) for at least $15 \mathrm{~min}$. They were then slowly injected intravenously during $2 \mathrm{~min}$ with either the angiotensin converting enzyme (ACE)-inhibitor enalaprilate $(25 \mu \mathrm{g} / \mathrm{kg}$ body weight; MSD International, Rahway, N. J., USA) or the corresponding volume $(0.2 \mathrm{ml})$ of saline. Other animals received an intravenous infusion $(0.1 \mathrm{ml} / \mathrm{min}$ for $10 \mathrm{~min})$ of saline, the ATII-receptor antagonist saralasin $\left(0.15\right.$ or $0.30 \mu \mathrm{g} \cdot \mathrm{kg}^{-1} \cdot \mathrm{min}^{-1}$; Sigma Chemicals, St. Louis, Mo., USA) dissolved in saline or ATII (Sigma) dissolved in saline $\left(2,50\right.$ or $\left.100 \mathrm{ng} \times \mathrm{min}^{-1}\right)$. The blood flow measurements were performed $10 \mathrm{~min}$ after the start of the injection, or after $10 \mathrm{~min}$ of infusion, respectively.

The blood perfusion of the whole pancreas, pancreatic islets and adrenal glands was determined with a microsphere technique as previously described in detail [10]. Briefly, 1.5$2.0 \times 10^{5}$ non-radioactive microspheres (NEN-Trac; DuPont Pharmaceuticals Inc., Wilmington, Del., USA), with a diameter of $11 \mu \mathrm{m}$, were injected during $10 \mathrm{~s}$ through the catheter with its tip in the ascending aorta. Starting $5 \mathrm{~s}$ before the microsphere injection, and continuing for a total of $60 \mathrm{~s}$, an arterial blood reference sample was collected by free flow (approximately $0.50 \mathrm{ml} / \mathrm{min}$ ) from the catheter placed in the femoral artery. The exact withdrawal rate in each experiment was controlled by weighing the sample. The animals were then killed and the whole pancreas and adrenal glands were removed, blotted and weighed. The organs were treated with a freezethawing technique which allows the visualisation and localisation of the microspheres to either the endocrine or the exocrine part of the pancreas [11]. The blood flow values were calculated according to the formula $\mathrm{Q}_{\text {org }}=\mathrm{O}_{\text {ref }} \times \mathrm{N}_{\text {org }} / \mathrm{N}_{\text {ref }}$, where $\mathrm{Q}_{\text {org }}$ is organ blood flow ( $\left.\mathrm{ml} / \mathrm{min}\right), \mathrm{Q}_{\text {ref }}$ withdrawal rate of the reference sample $(\mathrm{ml} / \mathrm{min}), \mathrm{N}_{\text {org }}$ number of mirospheres in the organ and $\mathrm{N}_{\text {ref }}$ the number of microspheres in the reference sample.

The blood flow to each of the adrenal glands was calculated in each experimental animal. A difference in adrenal blood flow less than $10 \%$ between the two glands was considered confirmatory of an adequate mixture of the microspheres with the circulation. Two animals were excluded from the study since they did not fulfil this criterion.

Measurements of glucose. In all experiments, the blood glucose concentrations were measured at the time of the blood flow measurements with ExacTech-blood glucose reagent strips (Baxter Travenol Laboratories Inc., Deerfield, Ill., USA) in arterial blood samples. Blood glucose concentrations were also determined immediately before infusion of saline or saralasin.

Perfusions of pancreas-duodenum. The animals were anaesthetized with an intraperitoneal injection of pentobarbital as given above, and placed on a heated operating table. The whole pancreas and duodenum were then removed from the animals as previously described $[12,13]$. The preparation was placed in a funnel, and kept at a constant temperature $\left(37^{\circ} \mathrm{C}\right)$ and humidity throughout the experiments. The secretions from the intestine and exocrine pancreas were diverted through a separate catheter in the duodenum. The pancreas-duodenum preparation was perfused at $1.5 \mathrm{ml} / \mathrm{min}$ without recirculation with a continuously gassed $\left(95 \% \mathrm{O}_{2}: 5 \% \mathrm{CO}_{2}\right)$ bicarbonate buffer [14], supplemented with $10 \mathrm{mmol} / \mathrm{l} \mathrm{Hepes} \mathrm{(Sigma)} \mathrm{and} 2 \mathrm{mg} /$ $\mathrm{ml}$ each of dextran (Dextran T70; Pharmacia Fine Chemicals, Uppsala, Sweden) and bovine serum albumin (Fraction V; Miles, Slough, UK). This basal medium was then further supplemented as given below.

All perfusions, with the exception for group $\mathrm{C}$ below, started with a 15-min equilibration period with basal medium supplemented with only $2.8 \mathrm{mmol} / \mathrm{l} \mathrm{D}$-glucose. After this, the perfusions followed one of the protocols outlined below with the following additions to the basal medium: A) $30 \mathrm{~min}$ with $16.7 \mathrm{mmol} / \mathrm{l} \mathrm{D}$-glucose; B) $15 \mathrm{~min}$ with enalaprilate $(25 \mu \mathrm{g} /$ $\mathrm{ml})+2.8 \mathrm{mmol} / \mathrm{l} \mathrm{D}$-glucose followed by $30 \mathrm{~min}$ with enalaprilate $(25 \mu \mathrm{g} / \mathrm{ml})+16.7 \mathrm{mmol} / \mathrm{l} \mathrm{D}$-glucose; C) $30 \mathrm{~min}$ with 10 $\mathrm{ng} / \mathrm{ml} \mathrm{ATII}+5.6 \mathrm{mmol} / \mathrm{l} \mathrm{D}$-glucose; D) $30 \mathrm{~min}$ with $10 \mathrm{ng} / \mathrm{ml}$ ATII $+16.7 \mathrm{mmol} / \mathrm{l}$ D-glucose; E) $10 \mathrm{~min}$ with $10 \mathrm{ng} / \mathrm{ml}$ ATII + $2.8 \mathrm{mmol} / \mathrm{l} \mathrm{D}$-glucose followed by $30 \mathrm{~min}$ with $10 \mathrm{ng} /$ $\mathrm{ml} \mathrm{ATII} \mathrm{+} 16.7 \mathrm{mmol} / \mathrm{l}$ D-glucose; F) $20 \mathrm{~min}$ with $10 \mathrm{ng} / \mathrm{ml}$ ATII $+2.8 \mathrm{mmol} / \mathrm{l} \mathrm{D}$-glucose followed by $30 \mathrm{~min}$ with $10 \mathrm{ng} /$ $\mathrm{ml} \mathrm{ATII} \mathrm{+} 16.7 \mathrm{mmol} / \mathrm{l} \mathrm{D}$-glucose; G) $15 \mathrm{~min}$ with $100 \mathrm{ng} / \mathrm{ml}$ angiotensin I (AT I; Sigma) + $2.8 \mathrm{mmol} / \mathrm{l} \mathrm{D-glucose}$ followed

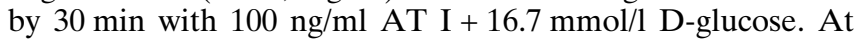
the end of all perfusions, except for group $\mathrm{C}$, a 15-min period with basal medium supplemented with only $2.8 \mathrm{mmol} / \mathrm{l} \mathrm{D}$-glucose was administered. Note that the glucose concentration in group $\mathrm{C}$ remained constant at $5.6 \mathrm{mmol} / 1$ throughout the whole perfusion period. Any perfusion in which the effluent insulin concentration was not markedly reduced towards the basal values, during the last 15-min period, were considered as technical failures and were excluded from the study.

The effluent medium from the preparations was sampled every $5 \mathrm{~min}$, except during the first $10 \mathrm{~min}$ after commencing a perfusion with any other medium than basal medium, when samples were collected in 1-min intervals after $1-5,7$ and $10 \mathrm{~min}$. The insulin concentrations in all samples were determined by radioimmunoassay [15].

The first and second phase of insulin response to glucose during the 30-min stimulation period with $16.7 \mathrm{mmol} / \mathrm{l}$ glucose was calculated by planimetry of the area of each individual perfusion curve for groups A, B, D, F, G [16].

Statistical analysis. All values are given as means \pm SEM. Statistical comparisons were made with Student's two-tailed unpaired or paired $t$-test. 
Table 1. Effect of angiotensin II infusion on blood glucose and blood pressure

\begin{tabular}{|c|c|c|c|c|}
\hline Substance given & Saline & AT II, $2 \mathrm{ng} / \mathrm{min}$ & AT II, $50 \mathrm{ng} / \mathrm{min}$ & AT II, $100 \mathrm{ng} / \mathrm{min}$ \\
\hline No of animals & 8 & 8 & 7 & 7 \\
\hline \multicolumn{5}{|c|}{ Blood glucose $(\mathrm{mmol} / \mathrm{l})$} \\
\hline \multicolumn{5}{|c|}{ Mean arterial blood pressure $(\mathrm{mm} \mathrm{Hg})$} \\
\hline $0 \mathrm{~min}$ & $118 \pm 5$ & $106 \pm 6$ & $111 \pm 9$ & $104 \pm 6$ \\
\hline
\end{tabular}

All values are means \pm SEM. ${ }^{a} p<0.001$ when compared with saline-infused rats. ${ }^{\mathrm{b}} p<0.05$ and ${ }^{\mathrm{c}} p<0.001$ compared with time 0 in the same group

Measurements were made 10 min after starting an infusion $(0.1 \mathrm{ml} / \mathrm{min})$ with saline or angiotensin II (AT II; 2,50 or $100 \mathrm{ng} / \mathrm{min}$ )

Table 2. Effect of angiotensin II on pancreatic and islet blood flow

\begin{tabular}{|c|c|c|c|c|}
\hline Substance given & Saline & AT II, $2 \mathrm{ng} / \mathrm{min}$ & AT II, $50 \mathrm{ng} / \mathrm{min}$ & AT II, $100 \mathrm{ng} / \mathrm{min}$ \\
\hline No of animals & 8 & 8 & 7 & 7 \\
\hline $\begin{array}{l}\text { Pancreatic blood flow } \\
\left(\mathrm{ml} \cdot \mathrm{min}^{-1} \cdot \mathrm{g}^{-1}\right)\end{array}$ & $0.92 \pm 0.15$ & $0.76 \pm 0.10$ & $0.54 \pm 0.07^{\mathrm{a}}$ & $0.41 \pm 0.06^{\mathrm{b}}$ \\
\hline $\begin{array}{l}\text { Pancreatic vascular conductance } \\
\left(\mu \mathrm{I} \cdot \mathrm{min}^{-1} \cdot \mathrm{g}^{-1} \cdot \mathrm{mmHg}^{-1}\right)\end{array}$ & $7.51 \pm 1.05$ & $5.83 \pm 0.78$ & $3.10 \pm 0.37^{\mathrm{c}}$ & $2.02 \pm 0.28^{c}$ \\
\hline Islet blood flow $\left(\mu \mathrm{l} \cdot \min ^{-1} \cdot \mathrm{g}^{-1}\right)$ & $45.4 \pm 7.2$ & $36.3 \pm 6.3$ & $45.3 \pm 6.1$ & $45.3 \pm 6.1$ \\
\hline Islet blood flow ( $\%$ pancreatic blood flow) & $5.1 \pm 0.4$ & $4.7 \pm 0.4$ & $8.6 \pm 0.9^{\mathrm{b}}$ & $11.2 \pm 1.0^{\mathrm{c}}$ \\
\hline
\end{tabular}

All values are means \pm SEM. ${ }^{\mathrm{a}} p<0.05,{ }^{\mathrm{b}} p<0.01$ and ${ }^{\mathrm{c}} p<0.001$ compared with saline-infused rats

Measurements were made $10 \mathrm{~min}$ after starting an infusion $(0.1 \mathrm{ml} / \mathrm{min})$ with saline or angiotensin II (AT II; $2,50 \mathrm{or} 100 \mathrm{ng} / \mathrm{min}$ )

Table 3. Effect of enalaprilate on blood glucose, blood pressure, and pancreatic and islet blood flow

\begin{tabular}{lll}
\hline $\begin{array}{l}\text { Substance given } \\
\text { No of animals }\end{array}$ & $\begin{array}{l}\text { Saline } \\
7\end{array}$ & $\begin{array}{l}\text { Enalaprilate } \\
7\end{array}$ \\
\hline $\begin{array}{l}\text { Blood glucose }(\mathrm{mmol} / \mathrm{l}) \\
\begin{array}{l}\text { Mean arterial blood pressure } \\
(\mathrm{mm} \mathrm{Hg})\end{array}\end{array}$ & $4.4 \pm 0.2$ & $4.5 \pm 0.1$ \\
$\begin{array}{l}\text { Pancreatic blood flow } \\
\left(\mathrm{ml} \cdot \mathrm{min}^{-1} \cdot \mathrm{g}^{-1}\right)\end{array}$ & $106 \pm 3$ & $110 \pm 3$ \\
$\begin{array}{l}\text { Islet blood flow }\left(\mu \mathrm{l} \cdot \mathrm{min}^{-1} \cdot \mathrm{g}^{-1}\right) \\
\begin{array}{l}\text { Islet blood flow } \\
(\% \text { of pancreatic blood flow) }\end{array}\end{array}$ & $33 \pm 3$ & $102 \pm 21^{\mathrm{a}}$ \\
\hline All values are means & $8.2 \pm 1.0$ & $16.7 \pm 1.5^{\mathrm{b}}$ \\
\hline
\end{tabular}

All values are means \pm SEM. ${ }^{\mathrm{a}} p<0.01$ and ${ }^{\mathrm{b}} p<0.001$ compared with the saline-injected rats

Measurements were made 10 min after an intravenous injection of $0.2 \mathrm{ml}$ saline or enalaprilate $(25 \mu \mathrm{g} / \mathrm{kg})$ dissolved in saline

\section{Results}

Blood flow measurements. Infusion of ATII induced a dose-dependent and pronounced hypertension in all animals (Table 1). Furthermore, administration of the two highest doses led to a slight hyperglycaemia (Table 1). ATII caused a dose-dependent decrease in both whole pancreatic and islet blood flow (Table 2). The decrease was of a similar magnitude at the two lowest doses ( 2 and $50 \mathrm{ng} / \mathrm{min}$ ) of ATII, as evidenced by the unchanged fractional islet blood flow values, whereas whole pancreatic blood flow was diminished to a larger extent than islet blood flow at the highest dose of ATII (100 ng/min; Table 2). The changes in blood flow values were mirrored by similar changes in the vascular conductance of the whole pancreas and islets, respectively (Table 2). Administration of enalaprilate did not affect mean arterial blood pressure or blood glucose concentrations when compared with saline-injected rats (Table 3 ). Neither could any changes in whole pancreatic blood flow be observed (Table 3). However, the islet blood flow was markedly increased, leading to an almost doubling of the fraction of whole pancreatic blood flow being diverted through the islets (Table 3). Saralasin selectively increased islet blood flow at the higher dose $\left(0.30 \mu \mathrm{g} \cdot \mathrm{kg}^{-1} \cdot \mathrm{min}^{-1}\right)$, whereas at the lower dose $\left(0.15 \mu \mathrm{g} \cdot \mathrm{kg}^{-1} \cdot \mathrm{min}^{-1}\right)$ both whole pancreatic and islet blood flow were increased (Table 4). Mean arterial blood pressure and blood glucose concentrations were not affected by saralasin administration (Table 4).

Perfusions of pancreas-duodenum. When control pancreas preparations were perfused (group A), addition of $16.7 \mathrm{mmol} / \mathrm{l} \mathrm{D}$-glucose to the medium elicited a biphasic insulin response (Fig.1). A prominent 
Table 4. Effect of saralasin on blood glucose, blood pressure, and pancreatic and islet blood flow

\begin{tabular}{llll}
\hline Substance given & Saline & Saralasin & $\left(0.30 \mu \mathrm{g} \cdot \mathrm{kg}^{-1} \cdot \mathrm{min}^{-1}\right)$ \\
\cline { 3 - 3 } No of animals & & $\left(0.15 \mu \mathrm{g} \cdot \mathrm{kg}^{-1} \cdot \mathrm{min}^{-1}\right)$ & 8 \\
\hline $\begin{array}{l}\text { Blood glucose }(\mathrm{mmol} / \mathrm{l}) \\
\quad \text { before infusion }\end{array}$ & 10 & 8 & $5.9 \pm 0.2$ \\
$\quad$ after infusion & $5.9 \pm 0.3$ & $5.5 \pm 0.3$ & $5.7 \pm 0.2$ \\
Mean arterial blood pressure $(\mathrm{mm} \mathrm{Hg})$ & $5.3 \pm 0.2$ & $5.9 \pm 0.3$ & $122 \pm 6$ \\
Pancreatic blood flow $\left(\mathrm{ml} \cdot \mathrm{min}^{-1} \cdot \mathrm{g}^{-1}\right)$ & $124 \pm 5$ & $125 \pm 8$ & $0.88 \pm 0.10$ \\
Islet blood flow $\left(\mu \mathrm{l} \cdot \mathrm{min}^{-1} \cdot \mathrm{g}^{-1}\right)$ & $0.78 \pm 0.09$ & $1.39 \pm 0.19^{\mathrm{c}}$ & $74 \pm 7^{\mathrm{b}}$ \\
Islet blood flow $(\%$ of pancreatic blood flow) & $45 \pm 7$ & $73 \pm 11^{\mathrm{a}}$ & $8.8 \pm 0.9^{\mathrm{b}}$ \\
\hline
\end{tabular}

Values are means \pm SEM. ${ }^{\mathrm{a}} p<0.05,{ }^{\mathrm{b}} p<0.02$ and ${ }^{\mathrm{c}} p<0.01$ compared with saline-infused rats

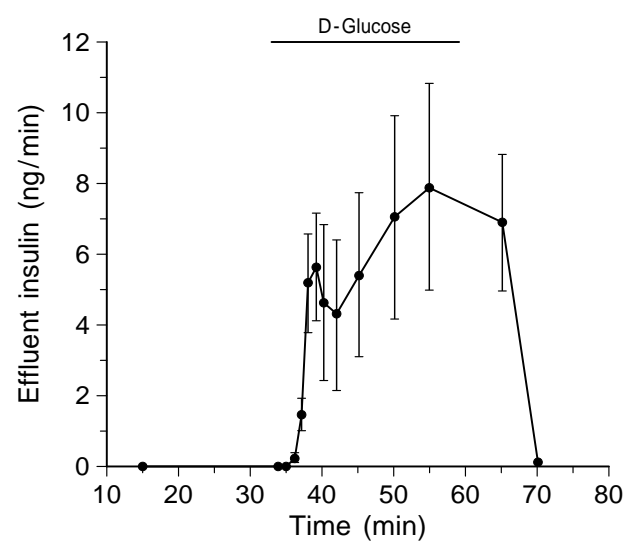

Fig. 1. Insulin concentrations in effluent medium collected from perfused pancreata of male Sprague-Dawley rats. After $30 \mathrm{~min}$ of perfusion with a medium containing $2.8 \mathrm{mmol} / \mathrm{l} \mathrm{D}$ glucose, insulin secretion was stimulated with a $30-\mathrm{min}$ period with $16.7 \mathrm{mmol} / 1 \mathrm{D}$-glucose (bar), followed by $15 \mathrm{~min}$ with $2.8 \mathrm{mmol} / \mathrm{l} \mathrm{D}$-glucose. Values represent mean $\pm \mathrm{SEM}$ of $7 \mathrm{ex}-$ periments

first peak was followed by a high and fairly constant second phase of insulin release, which promptly returned to basal values when the glucose stimulus was withdrawn (Fig.1). Addition of enalaprilate affected neither basal nor glucose-stimulated insulin release (Fig. 2). When ATII was added to a medium with $5.6 \mathrm{mmol} / \mathrm{l}$ glucose (group C) a slow increase in effluent insulin concentrations was seen up to $\approx 10 \mathrm{~min}$ after the start of the perfusion (Fig. 3) Thereafter the effluent insulin release decreased during $10 \mathrm{~min}$. When the medium was switched to basal medium with $5.6 \mathrm{mmol} / \mathrm{l}$ glucose an initial increase in effluent insulin concentrations was seen, but 15 min later the insulin release was once again decreased, although not to the low values seen before addition of ATII (Fig. 3). When ATII was added together with a high $(16.7 \mathrm{mmol} / \mathrm{l})$ glucose concentration, a marked change in the first phase of insulin release in response to glucose could be discerned. This was especially so
Measurements were made after an intravenous infusion $\left(0.1 \mathrm{ml} \cdot \mathrm{min}^{-1}\right.$ for $\left.10 \mathrm{~min}\right)$ of saline or saralasin $(0.15$ or $0.30 \mu \mathrm{g} \cdot \mathrm{kg}^{-1} \cdot \mathrm{min}^{-1}$ ) dissolved in saline

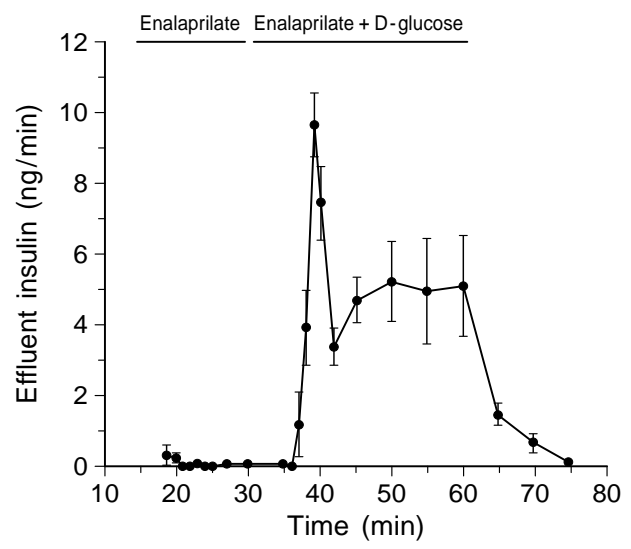

Fig. 2. Insulin concentrations in effluent medium collected from perfused pancreata of male Sprague-Dawley rats. Fifteen min of perfusion with a medium containing $2.8 \mathrm{mmol} / \mathrm{l} \mathrm{D}$-glucose was followed by $15 \mathrm{~min}$ with $2.8 \mathrm{mmol} / \mathrm{l} \mathrm{D}$-glucose + $25 \mu \mathrm{g} / \mathrm{ml}$ enalaprilate (first bar), $30 \mathrm{~min}$ with $16.7 \mathrm{mmol} / \mathrm{l} \mathrm{D}$ glucose $+25 \mu \mathrm{g} / \mathrm{ml}$ enalaprilate (second bar), and finally $15 \mathrm{~min}$ with only $2.8 \mathrm{mmol} / \mathrm{l} \mathrm{D}$-glucose. Values represent \pm SEM of 5 experiments

when ATII and glucose were added simultaneously (group D) where no first phase at all could be observed, whereas the second phase of insulin release remained unaffected (Fig. 4). When glucose was added 10 min after ATII had been added to the perfusion medium (group E), a minor first peak could barely be discerned, whereas, once again, the second phase insulin release was similar to that of the control pancreata in group A (Fig. 5). However, when glucose was given 20 min after that ATII had been added to the perfusion medium, the first phase of insulin release was restored (Fig. 6). It should be noted that the insulin release to the effluent medium during perfusion with only ATII was increased in group E (Fig. 5), similar to what was seen in group C. When AT I was added to the perfusion medium (group G) a normal first and second phase of insulin release could be seen (Fig. 7). A diminished first peak of insulin response was seen in group D when calculated as area under 


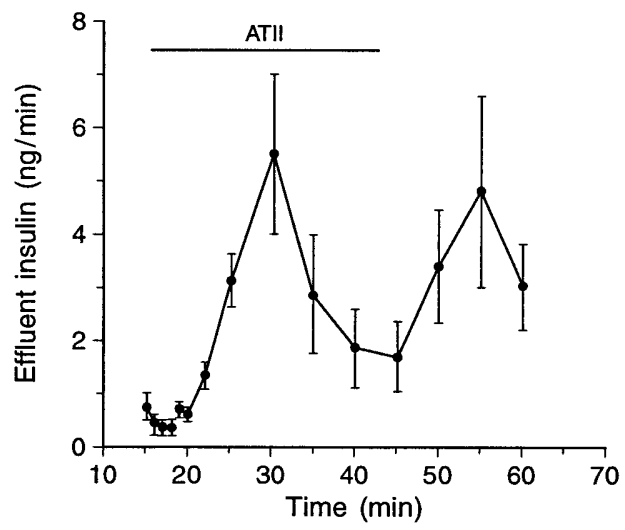

Fig.3. Insulin concentrations in effluent medium collected from perfused pancreata of male Sprague-Dawley rats. After $15 \mathrm{~min}$ of perfusion with a medium containing $5.6 \mathrm{mmol} / \mathrm{l}$ D-glucose, angiotensin II $(10 \mathrm{ng} / \mathrm{ml})$ was added for $30 \mathrm{~min}$ (bar), after which a final $15 \mathrm{~min}$ with only $5.6 \mathrm{mmol} / \mathrm{l} \mathrm{D}$-glucose commenced. Values represent mean \pm SEM of 6 experiments

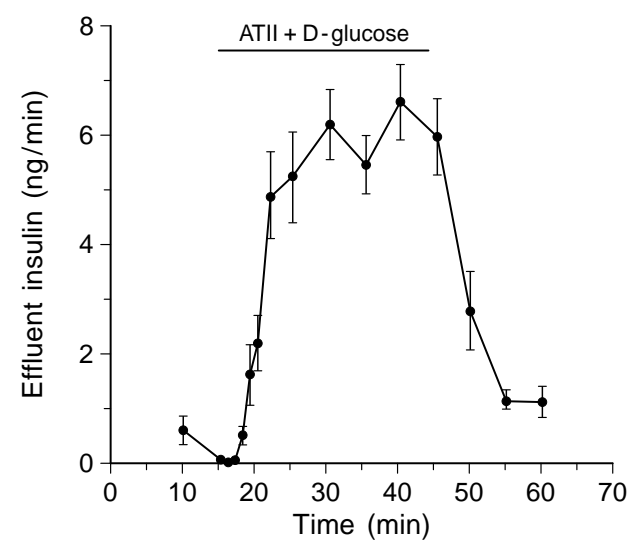

Fig.4. Insulin concentrations in effluent medium collected from perfused pancreata of male Sprague-Dawley rats. Fifteen min of perfusion with a medium containing $2.8 \mathrm{mmol} / \mathrm{l} \mathrm{D}$-glucose was followed by $30 \mathrm{~min}$ with $16.7 \mathrm{mmol} / \mathrm{l} \mathrm{D}$-glucose +10 $\mathrm{ng} / \mathrm{ml}$ angiotensin II (bar), and finally $15 \mathrm{~min}$ with only $2.8 \mathrm{mmol} / \mathrm{l} \mathrm{D}$-glucose. Values represent mean \pm SEM of $6 \mathrm{ex}-$ periments

curve ( $p<0.05$ vs group A; Student's unpaired $t$-test), whereas in the other groups $(B, F$ and $G)$ no differences were seen compared to control pancreata (data not shown).

\section{Discussion}

Blood flow to the pancreatic islets is regulated through a complex interaction between compounds released from the endocrine cells, locally produced endothelial-derived factors and nervous influences [see 17]. This results in an islet blood perfusion which is adequate both for the metabolism of the endocrine cells, and for the dispersal of the islet hormones. Islet

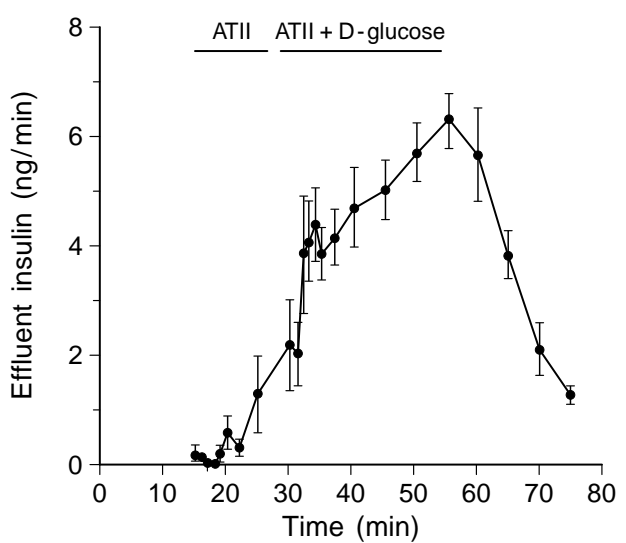

Fig. 5. Insulin concentrations in effluent medium collected from perfused pancreata of male Sprague-Dawley rats. Fifteen min of perfusion with a medium containing $2.8 \mathrm{mmol} / \mathrm{l} \mathrm{D}$-glucose was followed by $10 \mathrm{~min}$ with $2.8 \mathrm{mmol} / \mathrm{l} \mathrm{D}$-glucose +10 $\mathrm{ng} / \mathrm{ml}$ angiotensin II (first bar), $30 \mathrm{~min}$ with $16.7 \mathrm{mmol} / \mathrm{l} \mathrm{D}$-glucose $+10 \mathrm{ng} / \mathrm{ml}$ angiotensin II (second bar), and finally $15 \mathrm{~min}$ with only $2.8 \mathrm{mmol} / \mathrm{l} \mathrm{D}$-glucose. Values represent mean $\pm \mathrm{SEM}$ of 6 experiments

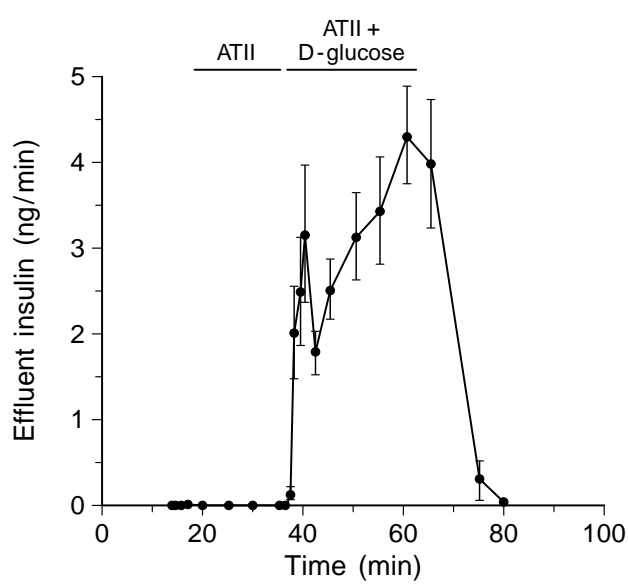

Fig. 6. Insulin concentrations in effluent medium collected from perfused pancreata of male Sprague-Dawley rats. Fifteen min of perfusion with a medium containing $2.8 \mathrm{mmol} / \mathrm{l} \mathrm{D}$-glucose was followed by $20 \mathrm{~min}$ with $2.8 \mathrm{mmol} / \mathrm{l} \mathrm{D}$-glucose +10 $\mathrm{ng} / \mathrm{ml}$ angiotensin II (first bar), $30 \mathrm{~min}$ with $16.7 \mathrm{mmol} / \mathrm{l} \mathrm{D}$-glucose $+10 \mathrm{ng} / \mathrm{ml}$ angiotensin II (second bar), and finally $15 \mathrm{~min}$ with only $2.8 \mathrm{mmol} / \mathrm{l} \mathrm{D}$-glucose. Values represent mean $\pm \mathrm{SEM}$ of 5 experiments

endothelial cells are able to produce more nitric oxide, i.e. the main endothelial-derived relaxing factor [18], than endothelial cells in the exocrine parts of the gland [19]. Furthermore, the islet vasculature seems to be more sensitive to regulatory influences of nitric oxide than the remaining parts of the pancreas [20]. These combined observations prompted us to investigate the effects on islet blood flow of another, mainly endothelial-derived, factor with profound effects on local blood flows, viz à viz ATII. This substance, and angiotensin III and angiotensin-(1-7) are produced in the canine pancreas in concentrations 


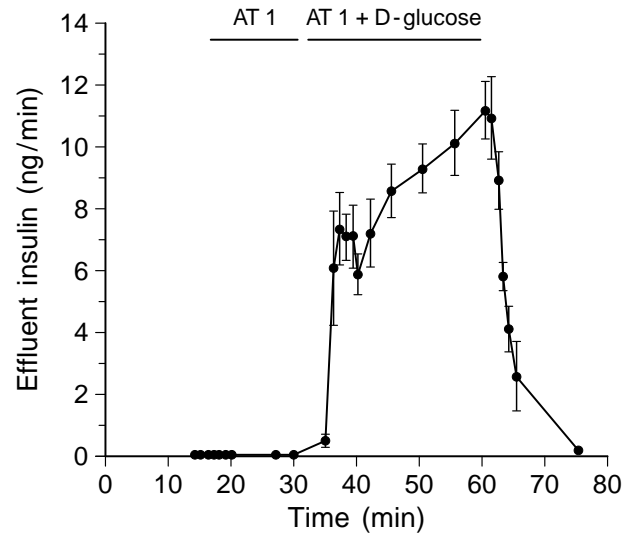

Fig.7. Insulin concentrations in effluent medium collected from perfused pancreata of male Sprague-Dawley rats. Fifteen min of perfusion with a medium containing $2.8 \mathrm{mmol} / 1 \mathrm{D}$-glucose was followed by $15 \mathrm{~min}$ with $2.8 \mathrm{mmol} / \mathrm{l} \mathrm{D}$-glucose +100 $\mathrm{ng} / \mathrm{ml}$ angiotensin I (first bar), $30 \mathrm{~min}$ with $16.7 \mathrm{mmol} / \mathrm{l} \mathrm{D}$-glucose $+100 \mathrm{ng} / \mathrm{ml}$ angiotensin I (second bar), and finally $15 \mathrm{~min}$ with only $2.8 \mathrm{mmol} / \mathrm{l} \mathrm{D}$-glucose. Values represent mean \pm SEM of 5 experiments

several times greater than those measured in peripheral blood [5]. ATII is the most abundant of these and is present in concentrations five times higher than the two other peptides [5]. Its receptors in the pancreas are found on both endocrine, exocrine and vascular tissue, and are mainly $\mathrm{AT}_{2}$-receptors, but also $\mathrm{AT}_{1}$-receptors are found in the canine pancreas. $[5,21]$.

The present results suggest that a basal intra-pancreatic production of ATII occurs also in the rat pancreas. In confirmation of a different sensitivity between endocrine and exocrine vascular systems, we observed that prevention of ATII-formation, by ACE inhibition with enalaprilate, preferentially increased islet blood flow. This finding suggests that islet microvessels may produce higher levels of ATII than microvessels in the exocrine pancreas, and therefore may be more sensitive to ACE-inhibition. Moreover, islet blood flow seems, under normal conditions, to be suppressed by this locally produced ATII. When ATII was administered exogenously both whole pancreatic and islet blood flow were decreased, but islet blood flow was affected less severely than the former. The discrepancy between these findings is likely to be explained by the fact that infusion of ATII produces similar concentrations of this substance at the resistance vessels in both the exocrine and endocrine pancreas. Interference with formation or binding of ATII, on the other hand, induced circulatory changes depending on the local endogenous concentrations of ATII, i.e. the islet circulation is likely to be more sensitive to these latter experimental conditions.

To exclude the possibility that the increased islet blood flow after ACE-inhibition was merely due to effects other than that on angiotensin, such as an inhibit- ed degradation of bradykinin, interaction with the prostaglandin system or the sympathetic nervous system [for review see 22], the effect on islet blood flow of an ATII receptor antagonist was also studied. AT, receptors seem to be preferentially associated with vascular effects, whereas the function of $\mathrm{AT}_{2}$-receptors is obscure [23]. Since previous studies in dogs, referred to above, suggest that the majority of ATII-receptors within the pancreas are of the $\mathrm{AT}_{2}$-type, we decided to choose saralasin, a non-specific ATII-receptor antagonist, for our experiments. Saralasin, like the ACE-inhibitor enalaprilate, increased islet blood flow. In the lower dose, saralasin increased both whole pancreatic blood flow and islet blood flow, whereas the higher dose selectively increased islet blood flow. This dose-dependent difference may be due to its previously described partly agonistic effects on ATII receptors [23]. Since both administration of the ATII-receptor antagonist saralasin and of the ACE-inhibitor enalaprilate increased islet blood flow, it can be envisaged that the effects of the latter on islet blood flow are at least partially mediated by decreased ATII production. Influence on islet blood flow of other effects of ACE-inhibition than decreased ATII-production, like increased levels of bradykinin, were beyond the scope of the present study.

Islet blood flow changes can be associated with changes also in insulin release from the pancreatic islets [cf. 17]. In view of the marked effects of ATII on islet blood flow, it could be envisaged that this substance would affect also the release of islet hormones in vivo. The animals given enalaprilate or saralasin in the present study showed no changes in blood glucose concentrations, whereas ATII caused a slight increase in blood glucose levels. This may be due to impaired insulin release, or perhaps more likely to a decreased glucose dispersal peripherally. In any case, a possible influence of ATII on insulin release seems subtle, and we therefore decided to use the perfused whole pancreas to study the effects of ATII on this process, since this model offers the possibility to evaluate insulin release on a minute-to-minute basis.

When enalaprilate was added to the perfusion medium no change in insulin release compared with controls was observed. This suggests, as expected, that the basal intra-pancreatic production of ATII is not necessary for a normal glucose-induced insulin release. Of more interest was the finding that ATII in itself could delay the first insulin peak after glucose stimulation, whereas the second-phase was unaffected. This was presumably due to the vasoconstrictive action of ATII. Indeed, there was an approximately 15 -min long $50 \%$ increase in perfusion pressure after addition of ATII to the medium, i.e. during the time of the first peak. Thereafter, the pressure returned to the basal value of approximately $50 \mathrm{~mm} \mathrm{Hg}(6.7 \mathrm{kPa}$; data not shown). The importance of vasoconstriction for the seemingly abolished first phase of insulin re- 
lease in group $\mathrm{D}$ was further emphasised by performing experiments in which a 20-min perfusion with a low glucose concentration plus ATII was followed by $30 \mathrm{~min}$ with high glucose and ATII (group F). This means that when high glucose was added to the medium, the vascular response to ATII had already declined, and no effects on perfusion pressure were seen during perfusion with high glucose plus ATII. In these experiments the first peak of insulin release was normalized. A reasonable explanation is that after 10-15 min of perfusion with ATII, local metabolites such as lactate and adenosine have accumulated and cause a metabolically mediated vasodilation. As the vasoconstriction disappears, insulin present in the islets will be washed out and the effluent insulin concentrations are momentarily increased (compare group $\mathrm{C}$ and $\mathrm{E}$ ).

As referred to above, the most prominent effect of ATII in the perfusion experiments was a delay of the first phase of glucose-stimulated insulin release. Several studies in hypertensive patients receiving longterm treatment with ACE-inhibitors, have described an increased early insulin peak in response to intravenous glucose administration $[24,25]$ or oral glucose [26]. Whether overactivity of the endothelium-dependent vasoconstriction in the islet microvasculature may contribute to the defective early insulin response in NIDDM [27] and gestational diabetes [28] remains to be shown.

In summary, the present study demonstrates that ATII has a marked vasoconstrictive effect on the vasculature of both the endocrine and exocrine pancreas. In view of the close correlation between islet blood flow and insulin release, a decreased islet blood flow, e.g. due to hyperactivity of the angiotensin system in the islet vasculature, could be of importance for impairments of insulin release.

Acknowledgements. The skilled technical assistance of Birgitta Bodin and Astrid Nordin is gratefully acknowledged. The study was supported by grants from the Swedish Medical Research Council (12X-109), the Novo Nordic Insulin Fund, the Family Ernfors Fund, the Göran Gustafsson Foundation and the Tore Nilsson Fund.

\section{References}

1. Vallottori MB (1987) The renin-angiotensin system. Trends Pharmacol Sci 8: 69-74

2. Suvannapura A, Levens NR (1988) Local control of mesenteric blood flow by the renin-angiotensin system. Am J Physiol 255:G267-G274

3. Campbell DJ, Habener JF (1986) Angiotensinogen gene is expressed and differentially regulated in multiple tissues of the rat. $\mathbf{J}$ Clin Invest 78: 31-39

4. Campbell DJ (1987) Circulating and tissue angiotensin systems. J Clin Invest 79: 1-6

5. Chappell MC, Millsted A, Diz DI, Brosnihan KB, Ferrario CM (1991) Evidence for an intrinsic angiotensin system in the canine pancreas. J Hypertens 9: 751-759
6. Dzau VJ, Kristin EE, Brody T, Ingelfinger J, Pratt RE (1987) A comparative study of the distributions of renin and angiotensinogen messenger ribonucleic acids in rat and in mouse and in rat tissues. Endocrinology 120: 2334-2338

7. Grove KI, Speth RC (1989) Rat epididymis contains functional angiotensin II receptors. Endocrinology 125: 223-230

8. Dunning BE, Moltz JH, Fawcett CP (1984) Actions of neurohypophysial peptides on pancreatic hormone release. Am J Physiol 246:E108-E114

9. Giani BU, Masini MA (1995) Angiotensin II binding sites in the rat pancreas and their modulation after sodium loading and depletion. Comp Biochem Physiol 111A:439-444

10. Jansson L, Hellerstrom C (1983) Stimulation by glucose of the blood flow to the pancreatic islets of the rat. Diabetologia 25: 45-50

11. Jansson L, Hellerstrom C (1981) A rapid method of visualizing the pancreatic islets for studies of islet capillary blood flow using nonradioactive microspheres. Acta Physiol Scand 113: 371-374

12. Loubatieres A, Mariani MM, Ribes G, De Malbosc H, Chapal J (1969) Etude expérimentale d'un nouveau sulfamide hypoglycémiant particuliérement actif, le HB 419 ou glibenclamide. 1. Action bétacytotrope et insulino-secretrice. Diabetologia 5: 1-10

13. Jansson L (1986) Flow distribution between the endocrine and exocrine parts of the isolated rat pancreas during perfusion in vitro with different glucose concentrations. Acta Physiol Scand 126: $533-538$

14. Krebs HA, Henseleit K (1932) Untersuchungen über die Harnstoffbildung im Tierkörper. Hoppe-Seyler's Z Physiol Chem 210: $33-66$

15. Heding LO (1972) Determination of total serum insulin (IRI) in insulin-treated diabetic patients. Diabetologia 8: 260-266

16. Korsgren O, Jansson L, Sandler S, Andersson A (1990) Hyperglycemia-induced B-cell toxicity. The fate of pancreatic islets transplanted into diabetic mice is dependent on their genetic background. J Clin Invest 86: 2161-2168

17. Jansson L (1994) The regulation of pancreatic islet blood flow. Diab Metabol Rev 10: 407-416

18. Moncada S, Palmer RMJ, Higgs EA (1991) Nitric oxide: physiology, pathophysiology, and pharmacology. Pharmacol Rev 43: 109-142

19. Suschek C, Fehsel K, Kröncke K-D, Sommer A, Kolb-Bachofen V (1994) Primary cultures of rat islet capillary endothelial cells. Constitutive and cytokine-inducible macrophage like nitric oxide syntheses are expressed and activities regulated by glucose concentration. Am J Pathol 145: 685-695

20. Svensson AM, Östenson C-G, Sandler S, Efendic S, Jansson L (1994) Inhibition of nitric oxide synthase by $\mathrm{N}^{\mathrm{G}}$-nitro-L-arginine causes a preferential decrease in pancreatic islet blood flow in normal rats and spontaneously diabetic GK rats. Endocrinology 135: 849-853

21. Chappell MC, Diz DI, Jacobsen DW (1992) Pharmacological characterisation of angiotensin II binding sites in the canine pancreas. Peptides 13: 313-318

22. Sunman W, Sever PS (1993) Non-angiotensin effects of angiotensin-converting enzyme inhibitors. Clin Sci 85: 661-670

23. Wong PC, Chiu AT, Duncia JV, Herblin WE, Smith RD, Timmermans PBMWM (1992) Angiotensin II receptor antagonists and receptor subtypes. Trends Endocrinol Metab 3: 211-217

24. Pollare T, Lithell H, Berne C (1989) A comparison of the effects of hydrochlorothiazide and captopril on glucose and lipid metabolism in patients with hypertension. N Engl J Med 321:868-873

25. Hanni A, Andersson PE, Lind L, Berne C, Lithell H (1994) Electrolyte changes and metabolic effects of lisinopril/bendrofluazide treatment. Results from a randomised, double-blind study with parallel groups. Am J Hypertension 7: 615-622

26. Santoro D, Natali A, Palombo C, Brandi LS, Piatti M, Ghione S, Ferrannini E (1992) Effects of chronic angiotensin converting enzyme inhibition on glucose tolerance and insulin sensitivity in essential hypertension. Hypertension 20: 181-191

27. Ward KV, Bolgiano DC, McKnight B, Halter JB, Porte D Jr (1984) Diminished B-cell secretory capacity in patients with non-insulindependent diabetes mellitus. J Clin Invest 74: 1318-1328

28. Ward KV, Johnston CLW, Beard JC, Benedetti TJ, Halter JB, Porte $\mathrm{D} \mathrm{Jr}$ (1985) Insulin resistance and impaired insulin secretion in subjects with histories of gestational diabetes mellitus. Diabetes 34: 861-869 